\title{
Future Projections of Fire Occurrence in Brazil Using EC-Earth Climate Model
}

\author{
Patrícia Silva $^{1}$, Ana Bastos ${ }^{2}$, Carlos C. DaCamara ${ }^{1}$, Renata Libonati ${ }^{3}$ \\ ${ }^{1}$ Instituto Dom Luiz, Faculdade de Ciências, Universidade de Lisboa, Lisboa, Portugal. \\ ${ }^{2}$ Laboratoire des Sciences du Climat et de l'Environnement, Universite Paris-Saclay, \\ Gif-sur-Yvette, France. \\ ${ }^{3}$ Departamento de Meteorologia, Instituto de Geociências, Universidade Federal do Rio de \\ Janeiro, Rio de Janeiro, Brazil.
}

Received: 30/11/2015 - Accepted: 7/5/2016

\begin{abstract}
Fire has a fundamental role in the Earth system as it influences global and local ecosystem patterns and processes, such as vegetation distribution and structure, the carbon cycle and climate. Since, in the global context, Brazil is one of the regions with higher fire activity, an assessment is here performed of the sensitivity of the wildfire regime in Brazilian savanna and shrubland areas to changes in regional climate during the 21 st Century, for an intermediate scenario (RCP4.5) of climate change. The assessment is based on a spatial and temporal analysis of a meteorological fire danger index specifically developed for Brazilian biomes, which was evaluated based on regional climate simulations of temperature, relative humidity and precipitation using the Rossby Centre Regional Climate Model (RCA4) forced by the EC-Earth earth system model. Results show a systematic increase in the extreme levels of fire danger throughout the 21 st Century that mainly results from the increase in maximum daily temperature, which rises by about $2{ }^{\circ} \mathrm{C}$ between 2005 and 2100 . This study provides new insights about projected fire activity in Brazilian woody savannas associated to climate change and is expected to benefit the user community, from governmental policies to land management and climate researches.
\end{abstract}

Keywords: fire danger, Brazil, Earth System Model, climate change.

\section{Projeções Futuras de Ocorrência de Fogo no Brasil Usando o Modelo EC-Earth}

\begin{abstract}
Resumo
O fogo tem um papel fundamental no Sistema Climático na medida em que influencia os padrões e os processos globais e locais dos ecossistemas, o ciclo do carbono e o clima. Tendo em conta que, no contexto global, o Brasil é uma das regiões com atividade de fogo mais elevada, pretende-se, no presente estudo, aferir da sensibilidade da ocorrência de fogo, nas áreas de savana e de vegetação arbustiva, às alterações climáticas durante o século XXI, para um cenário futuro intermédio (RCP4.5) de mudança climática. O estudo tem por bases análises espaço-temporais de um índice de perigo meteorológico de fogo, desenvolvido especificamente para os biomas do Brasil, cuja avaliação se baseou em simulações regionais do clima da temperatura, humidade relativa e precipitação, geradas pelo Modelo Regional (RCA4) do Rossby Centre forçado pelo modelo EC-Earth do sistema terrestre. Os resultados mostram a existência de um aumento sistemático dos níveis extremos de perigo de fogo ao longo do século XXI, o qual resulta principalmente de um crescimento de aproximadamente $2{ }^{\circ} \mathrm{C}$ dos valores diários da temperatura máxima entre 2005 e 2100 . Este trabalho abre perspetivas para o estudo das projeções da atividade de fogo no cerrado brasileiro, associadas a uma mudança climática, sendo de esperar que dele venham a beneficiar as comunidades de utilizadores, da política governamental à gestão do território e à investigação do clima.
\end{abstract}

Palavras-chave: risco de fogo, Brasil, Modelo Regional de Clima, mudanças climáticas. 


\section{Introduction}

Fire has a fundamental role in the Earth system, influencing global and local ecosystem patterns and processes, such as vegetation distribution and structure. Fires from human activities or natural causes release every year to the atmosphere about 2-4 PgC of radiatively and photochemically active trace gases and aerosols, an amount that represents roughly $30-50 \%$ of human emissions from fossil fuel burning (Bowman et al., 2009). The anticipated decrease of fuel moisture with higher temperatures and higher fuel loads due to the carbon fertilization effect is expected to intensify the frequency and extent of fire, which may lead to further spikes of carbon emissions (Alo and Wang, 2008). According to the Intergovernmental Panel on Climate Change (IPCC), climate change will likely increase the global risk of extreme fire events (IPCC, 2013). Furthermore, fire has impacts at the climatological, ecological, social and economic levels, such as those related to changes in the planetary albedo and the global radiative budget, modifications in vegetation condition, degradation potential of the soil and landscape value, damages to endangered species and adverse health effects of smoke haze (DaCamara et al., 2014).

In this context, Brazil is a key region, being one of the global areas most affected by fire (Bowman et al., 2009). Several studies focusing on the occurrence of fire in Brazil point out that tropical forests (especially the Amazonian forest), woody savannah (commonly referred to as cerrado), shrubs and grasslands, present the highest numbers of fire events that mainly relate to fire practices to convert natural vegetation to pasture and agriculture (Davidson et al., 2012; MCTI, 2013). In particular, the Brazilian woody savannas were pointed out as an endangered biome due to deforestation and fire practices (Spera et al., 2016; Shlisky et al., 2009; Pivello, 2011). Several studies based on models and observations highlighted South America as particularly vulnerable to climate change and have shown that semi-arid regions are an increasingly important driver of inter-annual variability in the carbon cycle, making the study of their future vulnerability to fire occurrence particularly relevant (Hoffmann et al., 2002; Magrin et al., 2007; Poulter et al., 2014).

In general, climate conditions are a fundamental driver of fire spread, and fire patterns are strongly sensitive to regional climate variability and change. For instance, the intra-annual variability of burnt area over the Brazilian woody savannah mostly relates to the seasonal regime of precipitation. There is a marked dry season from May to September, characterized by very low precipitation amounts and, during the dry period, there is a steady displacement towards higher values of the median, lower and upper quartiles and extremes of the distributions of monthly values of burnt area (Libonati et al., 2015). This displacement is in agreement with the increase in severity of dryness of the surface (Machado et al., 2014).
In future decades, Brazil is expected to have an increased likelihood of extreme weather events, together with an increase from moderate to high wildfire potential, as well as a longer fire season. However most of these conclusions derive from studies based on global indices (e.g. Liu et al., 2010), which are not tailored for the specific regional fire regimes under study.

Global Climate Models (GCMs) are useful tools to assess the evolution of fire behavior induced by future changes in the forcing variables. These models solve mathematical equations that describe the physical processes taking place in the atmosphere, the ocean, and the land surface. Earth System Models (ESMs) further include the biogeochemical processes (IPCC, 2013). These models are, therefore, useful to help understanding how the Earth's climate is changing and in anticipating natural and anthropogenically-driven variations in the future at the global scale. However, their coarse scale (typically in the order of a few degrees in latitude and longitude), limits the study of finer scale processes, as is the case of fire. In this regard, a great effort has been made by the scientific community in order to provide refined information about future climate using Regional Climate Models (RCMs). The Coordinated Regional Climate Downscaling Experiment (CORDEX) consists in a coordinated effort to develop a set of RCM experiments following a common protocol over regional domains, similar to the Coupled Model Intercomparison Project Phase 5 (CMIP5) framework for GCMs (Giorgi et al., 2009).

The aim of the present study is to assess the sensitivity of meteorological fire danger in Brazilian savannas and shrublands to changes in climate variables during the $21 \mathrm{st}$ Century, using an index of meteorological fire danger suited for the regional fire regime. This exploratory study was performed within the framework of the Brazilian FireLand-Atmosphere System (BrFLAS) Project. As a result from an initiative between Brazil and Portugal, Br-FLAS aims at advancing the scientific and technical knowledge regarding vegetation fires in Brazil namely in what concerns measuring areal and severity extent, estimating atmospheric emissions and transport, determining relations to observed past conditions and inferring possible implications by future climate scenarios (Libonati et. al., 2015).

For this purpose, we rely on the regional downscaling of EC-Earth for the CORDEX South American domain performed by the Rossby Centre Atmospheric regional model (RCA4, Samuelsson et al., 2011), which has been used in climate studies over South America for the CLARIS and CLARIS LPB projects (http://www.clariseu.org/). EC-Earth is known to simulate slightly colder and drier average conditions for the present day in most of South America (Hazeleger et al., 2012). In an inter-model comparison, a previous version of the RCA model has been shown to capture relatively well the seasonal cycle of temperature over three Brazilian regions, and to reproduce the 
main spatial distribution (Menéndez et al., 2010) and seasonal cycle of precipitation over the area (Solman et al., 2013).

Here we first evaluate the model ability to reproduce the fire risk and its drivers during the peak fire season. As the model is found to be fit for this study, we then analyze the evolution of fire from the present until the end of the 21 st Century. We focus on the future Representative Concentration Pathway (RCP) 4.5, which corresponds to a medium mitigation scenario covering the period 2005-2100 (IPCC, 2013). Fire danger is then assessed based on the so-called Meteorological Fire Danger Index (Sismanoglu and Setzer, 2004), that was developed in CPTEC/INPE, the Brazilian Center for Weather Forecasting and Climate Research at the Brazilian National Institute of Space Research. The last 30 years of the historical run (1976-2005) will finally be compared against two 30 year-periods of scenario RCP4.5 (2021-2050 and 2071-2100), paying special attention to changes in extreme classes of meteorological fire danger, the ones producing more devastating ecological and socio-economical impacts.

\section{Data and Methods}

\subsection{Area of study}

The analysis in the present study will focus on the Brazilian regions of savanna, woody savanna, and open and closed shrublands, where the highest number of fire events takes place (Davidson et al., 2012). Information on vegetation types over Brazil, required to assess fire risk, was obtained from IGBP's classification adapted for Brazil by INPE for the year 2005. As shown in Fig. 1, the original map (provided in a $1 \mathrm{~km} 1 \mathrm{~km}$ grid) was resampled to the model resolution (described in the next sub-section) by nearest-neighbor interpolation.

\subsection{Meteorological Fire Danger Index (MFDI)}

The assessment of fire risk relies on the so-called Meteorological Fire Danger Index (MFDI), which was internally developed at CPTEC/INPE based on the occurrence of hundreds of thousands of fire events in the main Brazilian biomes (Sismanoglu and Setzer, 2004). MFDI is operationally used at CPTEC (http://www.inpe.br/queimadas/) to assess fire danger and the aim of the index is to represent how predisposed vegetation is to be burned on a given day. The rationale is that the longer the time without rain, the higher the risk of vegetation to burn; defoliation (that depends on vegetation type), maximum temperature and min-

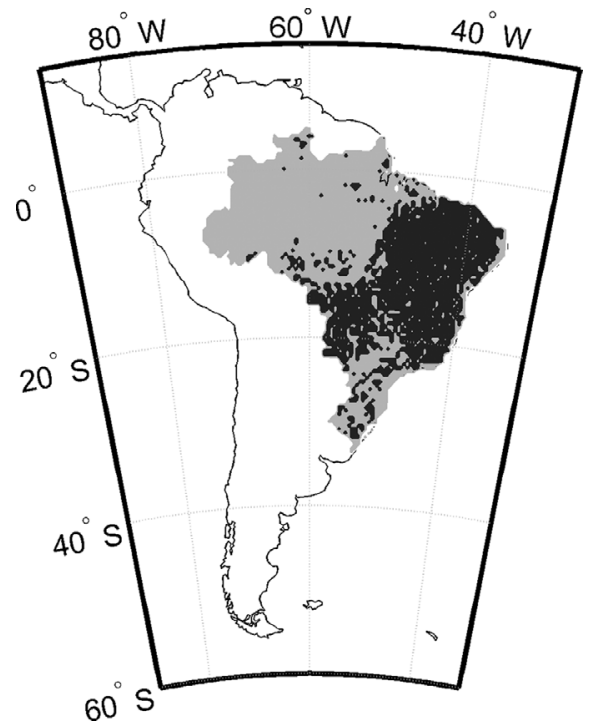

Figure 1 - Map of South America showing the study area (dark grey dots) covering the regions of savanna, woody savanna, and open and closed shrublands of Brazil (dark and light grey dots).

imum relative humidity are also taken into account. Wind speed is not included because it is a condition for fire spread, not fire ignition.

Computation of MFDI is based on information about vegetation cover and on daily values of the maximum temperature (henceforth referred to simply as $T$ ), minimum relative humidity $(R H)$ and accumulated precipitation $(P)$. First, the so-called Drought Day $(D D)$ index is evaluated for each day based on the product of 11 precipitation factors that take into account cumulated rainfall over 11 preceding periods:

$$
D D=\prod_{i=1}^{11} \exp \left(-\beta_{i} P_{i}\right)
$$

where $\beta_{i}$ and $P_{i}$ are respectively the decay factor and the accumulated precipitation for period $i$. Ranges and values of the decay factors for each period considered are given in Table 1. Each precipitation factor takes the form of an exponential decay and the aim is to reduce fire danger for higher volumes of rain in specific events and to attenuate the effect of precipitation as it occurs further in the past.

The so-called Base Danger $(B D)$ is then estimated for each day by combining $D D$ for that day with a sinusoidal curve that represents the effects of the phenology for the different vegetation types:

$$
B D=0.45\left\{1+\sin \left[\min \left(A \times D D, 180^{\circ}\right)-90^{\circ}\right]\right\}
$$

Table 1 - Ranges and values of the decay factors for the 11 periods that integrate the Drought Day (DD) index.

\begin{tabular}{lccccccccccccccccc}
\hline Period & 1 & 2 & 3 & 4 & 5 & 6 & 7 & 8 & 11 \\
\hline Range (in days) & 1 & 2 & 3 & 4 & 5 & $6-10$ & $11-15$ & $16-30$ & $31-60$ & $61-90$ & $91-120$ \\
Coefficient $(\beta)$ & -0.14 & -0.07 & -0.04 & -0.03 & -0.02 & -0.01 & -0.008 & -0.004 & -0.002 & -0.001 & -0.0007 \\
\hline
\end{tabular}


where the argument of the sinus function is in degrees and values of coefficient $A$ are 2.4 for closed savanna and closed shrubland and 3.0 for savanna and open shrubland. The form of the curve reflects the phenology of vegetation, that tends to follow the sinusoidal variation of intensity and duration of light along the year. The rationale of $B D$ is that for the same value of $D D$, the fire danger is higher e.g. for a pasture than for a forest.

Effects of relative humidity and air temperature are also taken into account, for each day, by means of the so-called Humidity Factor $(H F)$ and Temperature Factor $(T F)$, respectively defined as

$$
H F=-0.006 \times R H+1.3
$$

and

$$
T F=0.02 \times T+0.4
$$

Fire danger increases when relative humidity is below $40 \%$ and decreases when it is higher, whereas temperature has a linear effect, in which the fire danger increases with temperature values above $30{ }^{\circ} \mathrm{C}$ and decreases with lower values.

For each day, the value of $M F D I$ is finally obtained by multiplying the Basic Danger by the Humidity and Temperature Factors:

$$
M F D I=B D \times H F \times H T
$$

MFDI is dimensionless, and varies between zero and slightly above unity. $M F D I$ is then stratified into five classes, from low to critical levels, as specified in Table 2. A more detailed description of MFDI and its components may be found in Setzer and Sismanoglu (2012).

For all three study periods (1976-2005, 2021-2050 and 2071-2100), daily values of $D D, B D, H F, F T$ and $M F D I$ were computed for all pixels over the study area covering the Brazilian regions of savanna, woody savanna, and open and closed shrublands.

\subsection{Fire risk in the present}

In order to evaluate the skill of the model in capturing the main patterns associated with fire risk in Brazil, we first analyze the main spatio-temporal patterns of observed $T$, $R H$ and $P$, and the corresponding fire risk, calculated as described in the previous section. Daily fields of $T, R H$ and $P$

Table 2 - Classes of meteorological fire danger and respective ranges of the Meteorological Fire Danger Index (MFDI).

\begin{tabular}{lc}
\hline Danger & Range of $M F D I$ \\
\hline Minimum & $<0.15$ \\
Low & $0.15-0.40$ \\
Medium & $0.40-0.70$ \\
High & $0.70-0.95$ \\
Critical & $>0.95$ \\
\hline
\end{tabular}

were extracted from ERA-Interim Reanalysis (Dee et al., 2011) at 0.1 degree spatial resolution, for the period 19792005 , in order to match the last years of the historical simulation. All fields were aggregated to the $0.44^{\circ}$ rotated grid over South America corresponding to the CORDEX South American (SAM) domain.

\subsection{Regional climate model and simulations}

Simulations were obtained from the regional downscaling of the EC-Earth climate model for the CORDEX SAM domain, by the Rossby Centre Regional Climate Model (RCA4) (Jones et al., 2011, Samuelsson et al., 2011). The EC-Earth uses the Integrated Forecasting System (IFS) model to represent the atmosphere, the Nucleus for European Modelling of the Ocean (NEMO) model for the ocean, the Louvain-la-Neuve Sea Ice Model (LIM) model for the sea-ice, the Tiled ECMWF Scheme for Surface Exchanges over Land with revised land surface hydrology (HTESSEL) for the continental surfaces and vegetation, and the global chemistry Transport Model (TM5) for the atmospheric chemistry (although with no interactive coupling). Details about EC-Earth may be found in Hazeleger et al. (2012) and a detailed description of a previous version of the RCA model (RCA-3) is provided by Samuelsson et al. (2011). The new version includes information about soil properties, a new lake model and an improved hydrology (Berg et al., 2013). Vegetation in the model is used mainly as boundary condition to the atmosphere-surface physical exchanges, and is represented in a rather simplistic manner, based on the GLCC dataset derived from one year of AVHRR data (Loveland et al., 2000). Therefore, following the same procedure as in Section 2.3, we use the IGBP's map to calculate fire risk, as it is better suited for Brazil. This implies, however, that in the future simulations, vegetation is assumed to remain static, rather than responding to climate change, and thus the changes in fire risk simulated are due to changes in climate only.

Simulations are performed in a $0.44^{\circ}$ rotated grid over South America. Daily values of surface temperature, relative humidity and precipitation were extracted and selected for the study area for two simulations:

i) The recent historical period, performed for the years 1956-2005;

ii) The 21st Century (2006-2100), using the pathway RCP4.5, an intermediate mitigation scenario in which radiative forcing stabilizes at $4.5 \mathrm{~W} / \mathrm{m}^{2}$ in 2100 , assuming that technologies and strategies will be adopted for reducing greenhouse gas emissions (IPCC, 2013). Choice of a moderate scenario is to mitigate the drawback of using a static vegetation cover, which prevents taking into account the feedbacks of fire events on vegetation cover, that are expected to be much stronger in more severe scenarios such as RCP 8.5. 
On a first step, we analyze the performance of the $\mathrm{RCM}$ in reproducing the main spatiotemporal variability patterns of the climate drivers of fire risk during the peak of the fire season. As ERA-Interim is only available from 1979 onwards, and the calculation of fire risk on a given day requires information about precipitation during the preceding months, the comparison of modelled and observed fire risk patterns was performed for the period common to the observations and the historical period, i.e. 1980-2005.

To analyze the evolution of fire risk (and its drivers) over the 21 st Century, we select three 30 -yr long periods, the first one located at the end of the historical period (1976-2005) and the remaining two covering the last 30 years of the first (2021-2050) and the second (2071-2100) halves of the 21 st Century.

\section{Results and Discussion}

\subsection{Validation of fire danger simulated by the model}

The mean annual cycles of temperature, relative humidity, cumulated precipitation and fire danger over the study area during the 26-year period 1980-2005 were computed both for observed values (as evaluated by ERAInterim) and for modelled values (as simulated by RCA4EC-Earth), shown in Fig. 2. First, daily values of each variable were spatially averaged over the regions covered by savanna, woody savanna, and open and closed shrublands. Mean values of temperature, relative humidity and fire danger and values of cumulated precipitation were then computed for each month and year. Finally, for each month, values of inter-annual mean and of standard deviation were computed for each variable. All time series present strong seasonality, the austral summer months showing to be associated with high values of both relative humidity and precipitation (the rainy season) and with very low values of fire danger. The higher values of the latter take place in August and September (the dry season) and are consistent with the increasingly warmer and drier conditions (Machado et $a l ., 2014)$ that occur along that period of highest observed fire activity and largest recorded values of burned area (Libonati et al., 2015).

Systematic deviations are worth being noticed between observed and modelled values of all variables, namely a negative bias of about $2{ }^{\circ} \mathrm{C}$ along the whole year of both modelled temperature and fire danger relative to the observed ones and a positive bias of both simulated relative humidity and precipitation. This tendency for a rainier modelled annual cycle is consistent with the modelled wetter cycle, which in turn is consistent with the colder simulated cycle, i.e. with a weaker capacity of the atmosphere to retain water vapor. Finally, the lower danger for the modelled annual cycle is consistent with the colder, wetter and rainier simulated cycles. The modelled cycles also present a weaker inter-annual variability for each month than the observed cycles, which translates into lower values of monthly standard deviations of the simulated time series.

The month of September is especially conspicuous in terms of agreement between modelled and observed distributions of fire danger as well as of relative humidity and precipitation. As this period coincides with the peak in fire risk and in burnt area (Libonati et al., 2015), our analysis will focus on this month. The spatial distribution of the dif-
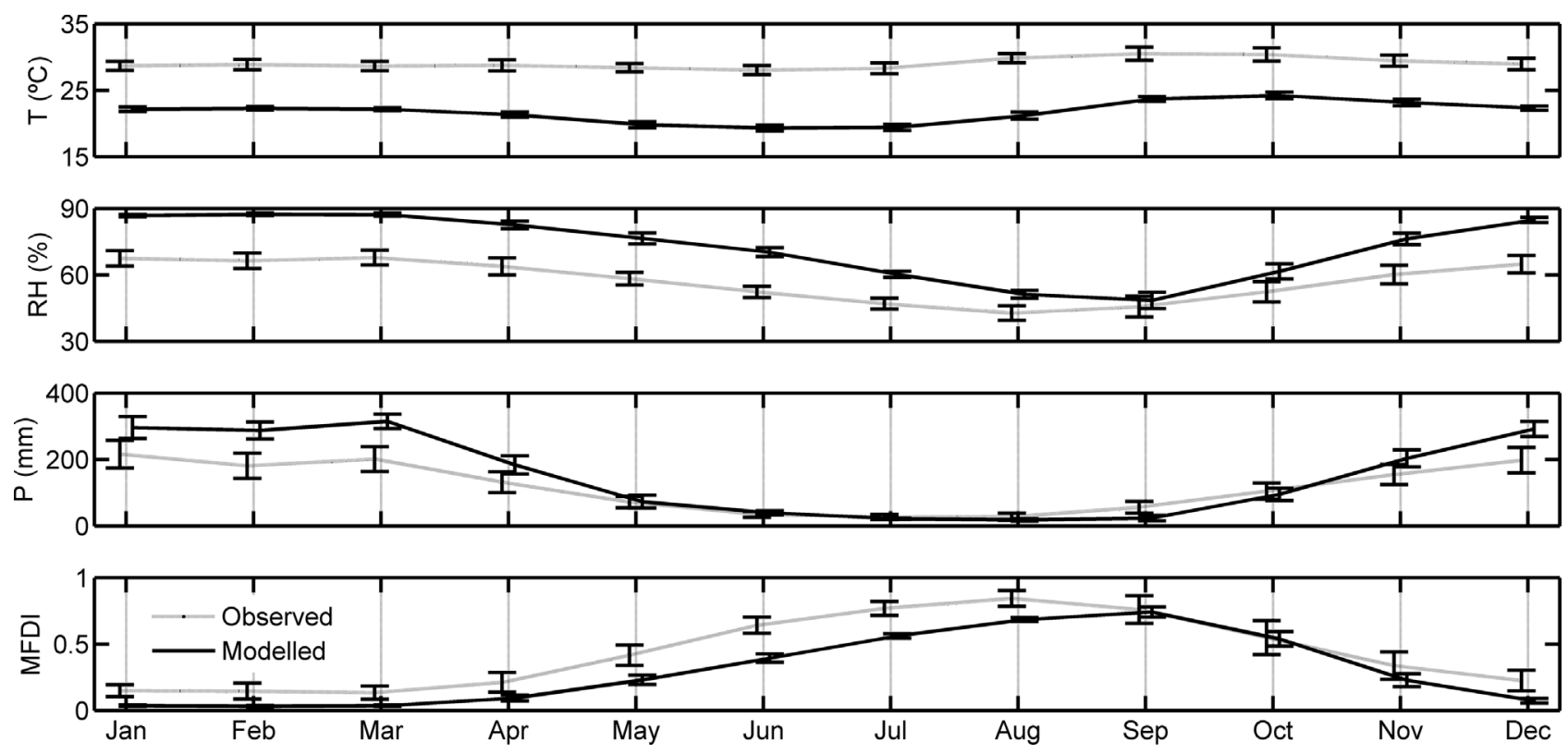

Figure 2 - Observed (black line) and simulated (grey line) annual cycles of monthly mean temperature $(T)$, relative humidity $(R H)$, cumulated precipitation $(P)$ and Meteorological Fire Danger Index (MFDI) over the study area for the common 26-year period 1980-2005, respectively derived from ERA-Interim Reanalysis and from the regional downscaling of the EC-Earth for the historical period. For each month, the vertical bars delimit the interval from minus to plus one standard deviation. 
ference between model and observations in September (not shown) reveals an east/west gradient, with fire risk being underestimated in the east and along the coast, progressively increasing towards the north-west of the region. This is largely due to overestimation of precipitation and relative humidity in the eastern areas and along the coastline, the two variables being underestimated in the interior and western areas. Nevertheless, in most pixels the differences are relatively small, with more than two thirds of the pixels showing absolute differences between modelled and observed values of fire danger lower than 0.2.

\subsection{Evolution of climate variables}

To better understand how meteorological drivers of fire are expected to evolve in the coming decades, the monthly mean values of temperature and relative humidity over the study region were calculated for the complete period of the historical run (1956-2005) and the 21st Century (2006-2100), using the pathway RCP4.5.

As shown in Fig. 3, during the historical period (solid lines) the model estimates a small increasing trend for temperature, and more variable patterns of relative humidity, which shows only signs of a persistent decreasing trend after the 1990's. For RCP4.5 (dashed lines), the model estimates a steady increase in temperature of about $2{ }^{\circ} \mathrm{C}$ over the Century, accompanied by a decrease of relative humidity of about $2 \%$. These results are in agreement with previous works (Grimm and Natori 2006; Marengo, et al., 2010, Sánchez et al., 2015) that performed evaluations of regional climate models over South America, showing an overall increase of temperature and a decrease of precipitation over central and eastern regions of the Amazon and Northeast Brazil. Low values of relative humidity cause fuels to dry out and become more flammable, and temperature is one of the most important factors when estimating fire risk considering that the higher the temperature the easier to ignite fuel (Pereira et al., 2013).
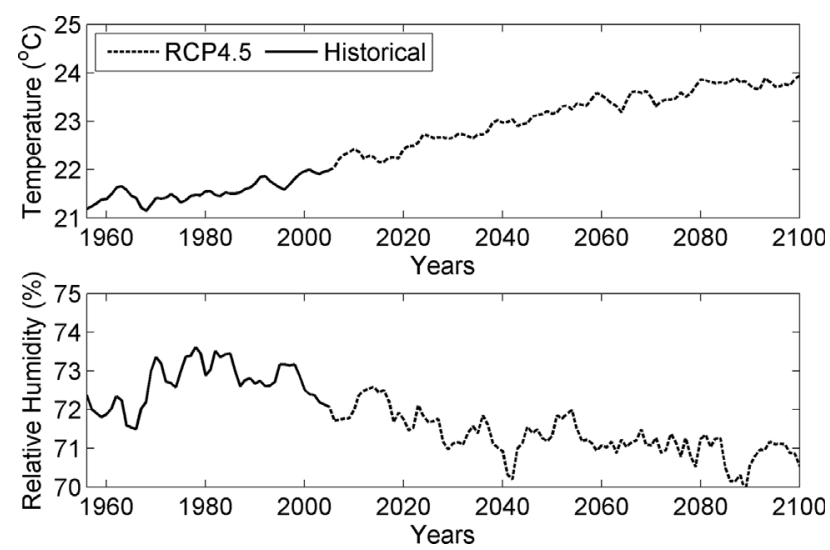

Figure 3 - Evolution of daily values of temperature (upper panel) and of relative humidity (lower panel) over the study area from 1956 to 2100 , covering the historical period of 1956-2005 (solid lines) and the future scenario RCP4.5 for 2005-2100, as estimated by the EC-Earth model (dashed lines).

\subsection{Evolution of meteorological fire danger}

Figure 4 compares the seasonal cycle of the Base Danger (BD), the Humidity and the Temperature Factors (HF and TF), and the resulting Meteorological Fire Danger Index (MFDI) for the three study periods of 1976-2005, 2021-2050 and 2071-2100. The cycle of BD (Fig. 4 - bottom left panel) for the historical period is consistent with the annual cycle of burned areas as described by Libonati et al. (2015), with very low values from December to April, increasing from May onwards and peaking in September. When comparing with the seasonal cycles for the two future projections, there are no distinguishable differences, which points to a negligible contribution of precipitation to possible changes in fire danger.

The HF component (Fig. 4 - upper right panel) presents a marked seasonal cycle, consistent with the dichotomy wet/dry season, peaking between September and October. When compared with HF, the TF component (Figure 4 - upper left panel) has a weaker seasonal cycle superimposed on a relatively high annual mean, with lower values during the austral winter (JJA) and increasing until October. A response to the climate forcing is observed for both TF and HF, but considerably higher for TF. While HF presents higher sensitivity to forcing from August to October, and a faster increase during the first half of the $21 \mathrm{st}$ Century (from 1976-2005 to 2021-2050), TF presents a similar increase of about 0.2 for the entire seasonal cycle and for each of the future periods.

As expected from the seasonal dynamics of the factors that compose the index, the annual cycle of MFDI (Fig. 4 - bottom right panel) presents values close to zero during the wet season (January to April), increasing until the peak in September and decreasing rapidly afterwards. Again, these results are consistent with those achieved by Libonati et al. (2015). The response to the climate forcing is registered mainly between July and October, but it is more pronounced in the peak month, i.e. September. Changes in MFDI regime in this month show an increase of the mean values from 1976-2005 to 2021-2050, and an increase in the mean and standard deviation values from 2021-2050 to 2071-2100 (Table 3).

The spatial distributions over the study area of mean values of MFDI for September are shown in Fig. 5 for the 30-yr study periods: the end of the historical period (19762005, left panel), and 2021-2050 (middle panel) and 20712100 (right) from the RCP4.5 simulation. For the historical run, a cross-continent region parallel to the Arc of Deforestation can be identified with mean values of MFDI greater than 0.70 , i.e. with above than medium levels of meteorological fire danger (Table 2). The two periods of the RCP4.5 simulation indicate in turn a widespread increase in mean values of MFDI from high to critical levels of meteorological fire danger over the above-mentioned region parallel to the Arc of Deforestation. 

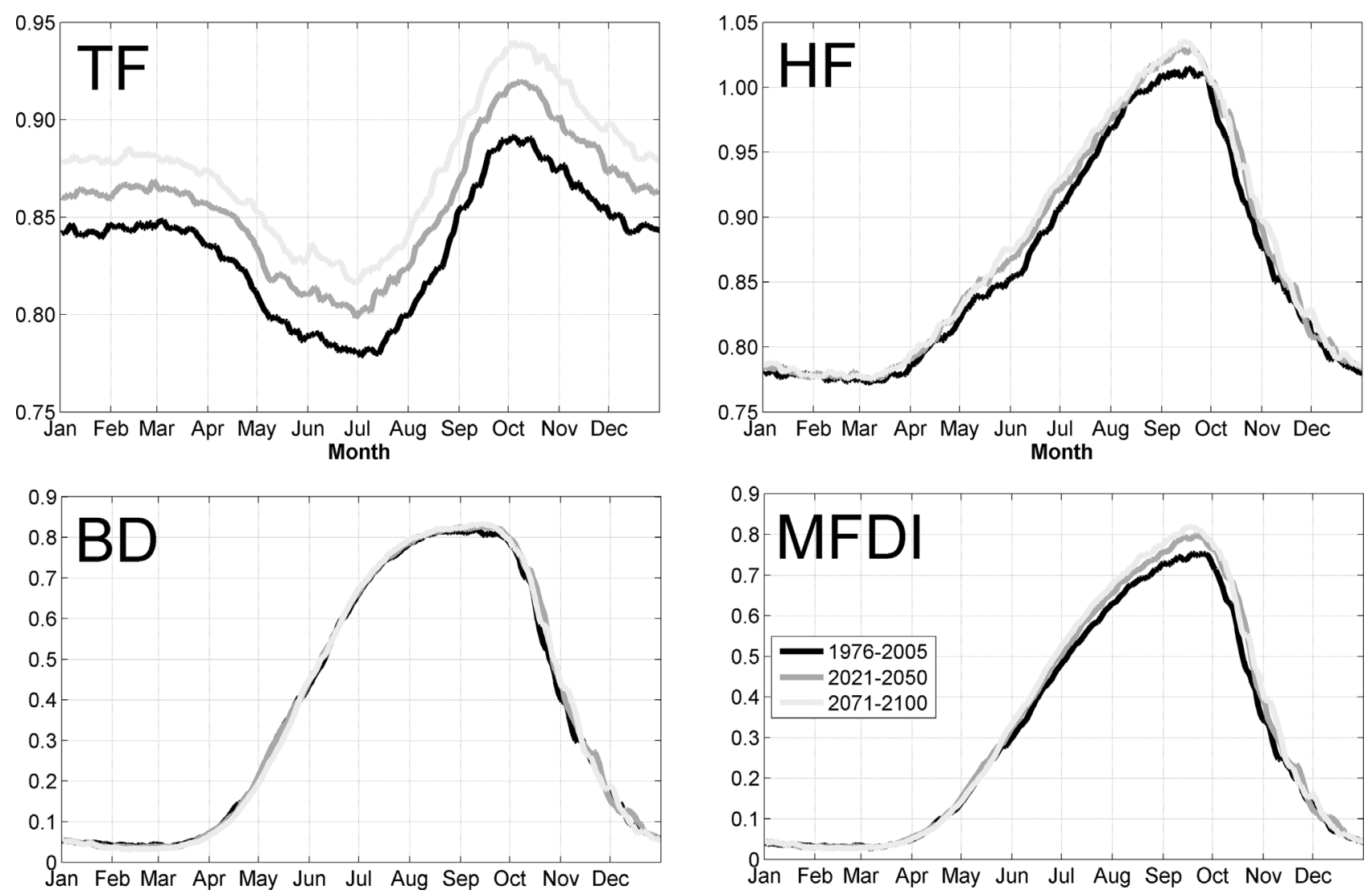

Figure 4 - Average seasonal cycle over the study area of the Temperature Factor ( $T F$, upper left panel), the Humidity Factor (HF, upper right panel), the Basic Danger ( $B D$, bottom left panel) and the Meteorological Fire Danger Index (MFDI, bottom right panel). The three curves represented respect to the study period of 1976-2005 (black line) of the historical run and the two study periods of 2021-2050 (dark-grey line) and 2071-2100 (grey line) of the RCP4.5 simulation.
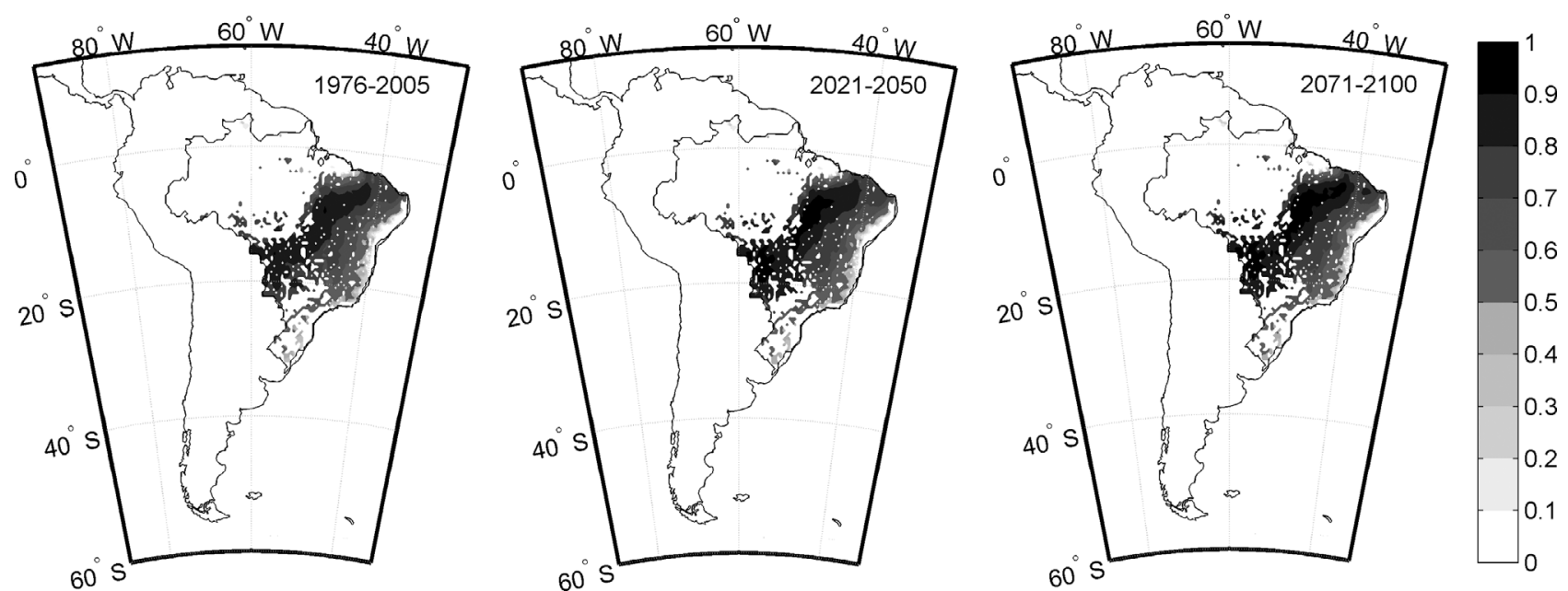

Figure 5 - Spatial distribution of monthly means of Meteorological Fire Danger Index (MFDI) in September for the study period of 1976-2005 (left panel) of the historical run and the two study periods of 2021-2050 (middle panel) and 2071-2100 (right panel) of the RCP4.5 simulation.

It is worth noting that simulated monthly values of MCDI for both 2021-2050 and 2071-2100 indicate that regions where a future increase in meteorological fire danger is likely to take place mostly match those regions where higher levels of MCDI values are also modeled for the historical run of 1976-2005. More severe fire seasons are therefore to be expected at the end of the 21 st Century. These results are in accordance with Liu et al. (2010), who 
Table 3 - Mean and standard deviation of MFDI for September over the study area covering the Brazilian savannas and shrublands, for the three study periods defined in the historical period (1976-2005) and in scenario RCP4.5 (2021-2050 and 2071-2100).

\begin{tabular}{lccc}
\hline & $\begin{array}{c}\text { Historical } \\
(1976-2005)\end{array}$ & $\begin{array}{c}\text { RCP4.5 } \\
(2021-2050)\end{array}$ & $\begin{array}{c}\text { RCP4.5 } \\
(2071-2100)\end{array}$ \\
\hline Mean & 0.74 & 0.78 & 0.80 \\
Standard deviation & 0.05 & 0.04 & 0.06 \\
\hline
\end{tabular}

analyzed trends in global wildfire potential in a changing climate.

The expected increase in severity of the fire season may be assessed by analyzing changes in the frequencies of occurrence of the five classes of meteorological fire danger (Table 2) paying special attention to changes in classes of higher danger that favor the onset of large fire events. Fig. 6 shows the present of MFDI classes calculated on a pixelby-pixel basis and their corresponding evolution over the 21 st Century. A systematic increase of days of critical fire danger is projected, from about $20 \%$ in the present to $28 \%$ in 2021-2050 and 32\% in 2071-2100. The remaining classes present a decrease over the course of the Century, with the larger decreases observed for the regions that present moderate to high fire risk in the present.

\section{Concluding Remarks}

This feasibility study intended to evaluate the applicability of using outputs from a Regional Climate Model (RCM) combined with a regionally-fit fire index to evaluate meteorological fire danger patterns in the Brazilian savannas and shrublands. The RCM (RCA4 forced by ECEarth) was able to reproduce the main seasonal patterns of fire occurrence in this region, and allowed evaluating the sensitivity of fire danger to the expected changes in the driving climate variables.

In this study, a systematic increase in the critical class of meteorological fire danger is observed in Brazilian

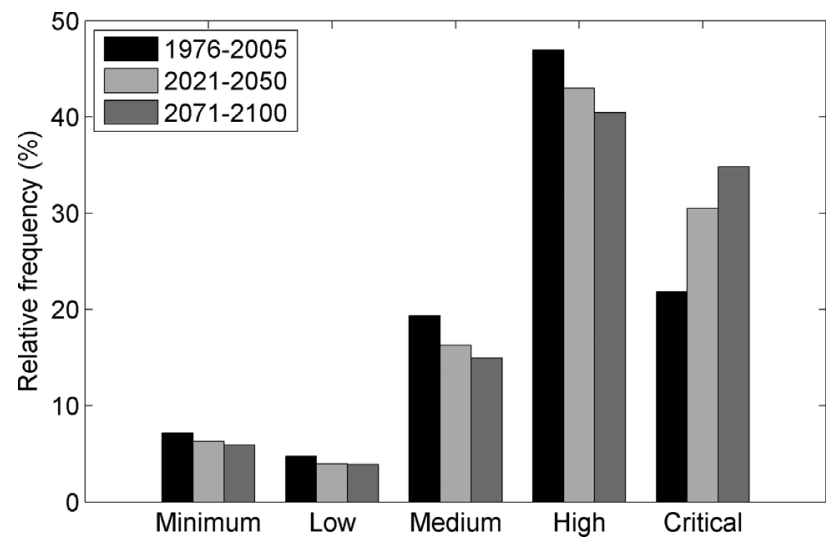

Figure 6 - Relative frequency of occurrence (\%) of classes of meteorological fire danger for the three study periods of 1976-2005 (historical run) and of 2021-2050 and 2071-2100 (RCP4.5 simulations). semi-arid biomes throughout the 21 st Century, for an intermediate scenario of climate change. The higher fire danger expected in the future mainly results from the increase in maximum daily temperature that reaches about $2{ }^{\circ} \mathrm{C}$ between 2005 and 2100.

The less marked role of humidity and precipitation may be attributed to the fact that vegetation (i.e. fuel) in these biomes is already quite dry during the fire season, turning the decrease in relative humidity and precipitation less determinant for future fire behavior. This may not be the case for other biomes in Brazil, such as the Amazon forest.

The simulated spatial distribution patterns of meteorological fire danger over the projected future point towards an overall increase of danger over a large area along the Arc of Deforestation. This increase together with the intensification of occurrence of classes of critical meteorological fire danger supports the likelihood of more severe fire seasons in savanna and shrubland regions in Brazil along the 21 st Century.

It is worth noting that, in order to account for possible biases or other error sources, a comparison of fire risk simulated by a set of models, rather than one, would allow estimating the uncertainty range of the future fire risk trajectories, and their dependence on changes in meteorological variables. Although the model performs relatively well during the peak fire season, there are important biases in the driving climatic variables, which may affect future projections of fire risk. Furthermore, the vegetation map used in this study was static, which is not realistic because vegetation is also expected to respond to changes in both climate and fire danger. Feedbacks between fire regime changes and vegetation cover have to be taken into account. In fact, fire is known to control the forest/savannah/grassland gradient (Staver et al., 2011) and, therefore, an increase of fire frequency, area or intensity might induce changes in vegetation composition in these regions. This could be taken into consideration by using dynamical vegetation models forced by future climate conditions, which are able to simulate changes in fuel structure and dryness and vegetation composition in response to both future climate and fire.

These two aspects are, however, beyond the scope of this work where the main goal was to assess the future changes in potential fire activity that can be expected from changes in climate variables due to human-induced climate change. Future work may include performing a more thorough validation/verification of the RCM RCA4-EC-Earth, and expanding the present study to other future scenarios and biomes, particularly the Amazon forest.

\section{ACKNOWLEDGMENTS}

Research performed was supported by FAPESP/FCT Project Brazilian Fire-Land-Atmosphere System (BrFLAS) (FAPESP/1389/2014; 2015/01389-4) and by 
EUMETSAT Satellite Application Facility for Land Surface Analysis (LSA SAF).

\section{References}

ALO, C.A.; WANG, G. Potential future changes of the terrestrial ecosystem based on climate projections by eight general circulation models. Journal of Geophysical Research, v. 113, 2008.

BERG, P.; DÖSCHER, R.; KOENIGK, T. Impacts of using spectral nudging on regional climate model RCA4 simulations of the Arctic. Geoscientific Model Development, v. 6, n. 3, p. 849-859, 2013.

BOWMAN, D.M.; BALCH, J.K.; ARTAXO, P.; BOND, W.J.; CARLSON, J.M.; et al. Fire in the earth system. Science, v. 324, p. 481-484, 2009.

DACAMARA, C.C.; CALADO, T.J.; ERMIDA, S.L.; TRIGO, I.F.; AMRAOUI, M.; TURKMAN, K.F. Calibration of the Fire Weather Index over Mediterranean Europe based on fire activity retrieved from MSG satellite imagery. International Journal of Wildland Fire, v. 23, n. 7, p. 945-958, 2014.

DAVIDSON, E.A.; DE ARAÚJO, A.C.; ARTAXO, P.; BALCH, J.K.; BROWN, I.F.; et al. The amazon basin in transition. Nature, v. 481, n. 7381, p. 321-328, 2012.

DEE, D.P.; UPPALA, S.M.; SIMMONS, A.J.; BERRISFORD, P.; POLI, P.; et al.. The ERA-Interim reanalysis: Configuration and performance of the data assimilation system. Quarterly Journal of the Royal Meteorological Society, v. 137(656), p. 553-597, 2011.

GIORGI, F.; JONES, C.; ASRAR, G.R. Addressing climate information needs at the regional level: the CORDEX framework. World Meteorological Organization (WMO) Bulletin, v. 58, n. 3, p. 175-183, 2009.

GRIMM, A.; NATORI, A. Climate change and interannual variability of precipitation in South America. Geophys Res Lett, v. 33:L19706, 2006.

HAZELEGER, W.; WANG, X.; SEVERIJNS, C.; STEFANESCU, S.; BINTANJA, R.; et al. EC-Earth V2.2: description and validation of a new seamless earth system prediction model. Climate Dynamics, v. 39, n. 11, p. 2611-2629, 2012.

HOFFMANN, W.; SCHROEDER, W.; JACKSON, R. Positive feedbacks of fire, climate, and vegetation and the conversion of tropical savanna. Geophysical Research Letters, v. 29, n. 22, p. 2052, 2002.

INTERGOVERNMENTAL PANEL ON CLIMATE CHANGE. Climate Change 2013: The Physical Science Basis. Contribution of Working Group I to the Fifth Assessment Report of the Intergovernmental Panel on Climate Change. Cambridge University Press, Cambridge, United Kingdom and New York, NY, USA, 2013. 1535 p.

JONES, C.; GIORGI, F.; ASRAR, G. The Coordinated Regional Downscaling Experiment: CORDEX, An international downscaling link to CMIP5. Clivar Exchanges, v. 16, n. 2, p. 34-40, 2011.

LIBONATI, R.; DACAMARA, C.C.; SETZER, A.W.; MORELLI, F.; MELCHIORI, A.E. An Algorithm for Burned Area Detection in the Brazilian Cerrado Using $4 \mu \mathrm{m}$ MODIS Imagery. Remote Sensing, v. 7, p. 15782-15803, 2015.
LIU, Y.; STANTURF, J.; GOODRICK, S. Trends in global wildfire potential in a changing climate. Forest Ecology and Management, v. 259, n. 4, p. 685-697, 2010.

LOVELAND, T.R.; REED, B.C.; BROWN, J.F.; OHLEN, D.O.; ZHU, Z.; et al. Development of a global land cover characteristics database and IGB6 DISCover from the $1 \mathrm{~km}$ AVHRR data. Int. J. Remote Sensing, v. 21, p. 1303-1330, 2000.

MACHADO, N.G.; DA SILVA, F.C.P.; BIUDES, M.S. Efeito das condições meteorológicas sobre o risco de incêndio e o número de queimadas urbanas e focos de calor em CuiabáMT, Brasil. Ciência e Natura, Santa Maria, v. 36, n. 3, p. 459-469, 2014.

MAGRIN, G.; GAY GARCÍA, C.; CRUZ CHOQUE, D.; GIMÉNEZ, J.C.; MORENO, A.R.; et al. Latin america. Climate Change 2007: Impacts, Adaptation and Vulnerability. Contribution of Working Group II to the Fourth Assessment Report of the Intergovernmental Panel on Climate Change. Cambridge University Press, Cambridge, UK, 2007. p. 581-615.

MARENGO, J.A.; AMBRIZZI, T.; DA ROCHA, R.P.; ALVES, L.M.; CUADRA, S.V.; et al. Future change of climate in South America in the late twenty-first Century: intercomparison of scenarios from three regional climate models. Clim Dyn, v. 35, n. 6, p. 1073-1097, 2010.

MENÉNDEZ, C.G.; DE CASTRO, M.; SORENSSON, A.; BOULANGER, J.-P. CLARIS project: towards climate downscaling in South America. Meteorologische Zeitschrift, E. Schweizerbart'sche Verlagsbuchhandlung, v. 19, p. 357$362,2010$.

Ministério da Ciência, Tecnologia e Inovação (MCTI). Estimativas Anuais de Emissões de Gases de Efeito Estufa no Brasil. MCTI, Brasília, 2013. Available on: http://www.mct.gov.br/upd_blob/0226/226591.pdf. Accessed on: 25 nov. 2015.

PEREIRA, M.G.; CALADO, T.J.; DACAMARA, C.C.; CALHEIROS, T. Effects of regional climate change on rural fires in Portugal. Climate Research., v. 57, n. 3, p. 187-200, 2013.

PIVELLO, V. The use of fire in the Cerrado and Amazonian rainforests of Brazil: Past and present. Fire Ecol., v. 7, p. 24-39. 2011.

POULTER, B.; FRANK, D.; CIAIS, P.; MYNENI, R.B.; ANDELA, N.; et al. Contribution of semi-arid ecosystems to interannual variability of the global carbon cycle. Nature, v. 509, p. 600-603, 2014.

SAMUELSSON, P.; JONES, C.G.; WILLÉN, U.; ULLERSTIG, A.; GOLLVIK, S.; et al. The Rossby Centre Regional Climate model RCA3: model description and performance. Tellus A, v. 63, n. 1, p. 4-23, 2011.

SÁNCHEZ, E.; SOLMAN, S.; REMEDIO, A.R.C.; BERBERY, H.; SAMUELSSON, P.; et al. Regional climate modelling in CLARIS-LPB: a concerted approach towards twentyfist Century projections of regional temperature and precipitation over South America. Clim Dyn, v. 45, p. 2193-2212, 2015;

SETZER, A.W.; SISMANOGLU, R.A. Risco de Fogo: Metodologia do Cálculo - Descrição sucinta da Versão 9. Instituto Nacional de Pesquisas Espaciais (INPE), 2012. Available at: 
http:/queimadas.cptec.inpe.br/ rqueimadas/documentos/R iscoFogo_Sucinto.pdf. Accessed on: 25 nov. 2015.

SISMANOGLU, R.A.; SETZER, A.W. Risco de fogo para a vegetação da América do Sul: comparação de duas versões para 2003. In: XIII Congresso Brasileiro de Meteorologia, SBMET, Fortaleza, CE, set. 2004. Available at: http://sigma.cptec.inpe.br/queimadas/documentos/200409 sismanoglu\&setzer_cbmet8_fortaleza_636.pdf. Accessed on: 25 nov. 2015.

SHLISKY, A.; ALENCAR, A.A.C.; NOLASCO, M.M.; CURRAN, L.M. Global fire regime conditions, threats, and opportunities for fire management in the tropics. Tropical Fire Ecology, Part of the series Springer Praxis Books, Heidelberg, Germany, 2009, pp 65-83.
SOLMAN, S.; SANCHEZ, E.; SAMUELSSON, P.; DA ROCHA, R.; LI, L.; et al. Evaluation of an ensemble of regional climate model simulations over South America driven by the ERA-Interim reanalysis: model performance and uncertainties. Climate Dynamics, v. 41, p. 1139-1157, 2013.

SPERA, S.A.; GALFORD, G.L.; COE, M.T.; MACEDO, M.N.; MUSTARD, J.F. Land-Use Change Affects Water Recycling in Brazil's Last Agricultural Frontier. Global Change Biology, doi:10.1111/gcb.13298, 2016.

STAVER, A.C.; ARCHIBALD, S.; LEVIN, S.A. The Global Extent and Determinants of Savanna and Forest as Alternative Biome States. Science, v. 334, n. 6053, p. 230-232, 2011.

All the contents of this journal, except where otherwise noted, is licensed under a Creative Commons Attribution License CC-BY. 